\title{
Heavy Particulate Matter Pollution during the 2014-2015 Winter in Tianjin, China
}

\author{
Zhenli Sun ${ }^{1}$, Fengkui Duan ${ }^{1 *}$, Yongliang Ma ${ }^{1,2}$, Kebin $\mathrm{He}^{1,2^{* *}}$, Lidan Zhu ${ }^{1}$, Tao Ma ${ }^{1}$ \\ ${ }^{1}$ State Key Joint Laboratory of Environment Simulation and Pollution Control, School of Environment, Tsinghua \\ University, Beijing 100084, China \\ ${ }^{2}$ State Environmental Protection Key Laboratory of Sources and Control of Air Pollution Complex, Tsinghua University, \\ Beijing 100084, China
}

\begin{abstract}
Tianjin, a city located in North China, is heavily polluted with frequent haze, particularly in winter. In this study, continuous online field observations of the sulfate, nitrate, ammonium, $\mathrm{PM}_{2.5}$, and gaseous pollutant concentrations in addition to the meteorological parameters were conducted in Tianjin during the 2014-2015 winter (December-JanuaryFebruary). The $\mathrm{PM}_{2.5}$ concentrations ranged from 5.6 to $495.6 \mu \mathrm{g} \mathrm{m}^{-3}$, with an average value of $112.2 \pm 96.1 \mu \mathrm{g} \mathrm{m}{ }^{-3}$. The worst pollution was observed in January, when levels on $10 \%$ of the days exceeded $250 \mu \mathrm{g} \mathrm{m}^{-3}$, qualifying as severely polluted, and four haze episodes, each lasting 5-7 days, occurred in rapid succession (separated by $\sim 1$-day intervals). Back-trajectory and chemical composition analysis suggested that elevated levels of secondary ionic aerosol species were a primary cause of these episodes. Regional transport of $\mathrm{PM}_{2.5}$ also played a large role in the formation of haze. CO was selected as an inactive chemical tracer in studying the chemical process of $\mathrm{PM}_{2.5}$ formation. The results indicated that when high concentrations of $\mathrm{PM}_{2.5}$ were present, the formation of secondary $\mathrm{PM}_{2.5}$ increased while the photochemical production of $\mathrm{O}_{3}$ ceased. The sulfur oxidation ratio $\left[\mathrm{SOR}=\mathrm{nSO}_{4}{ }^{2-} /\left(\mathrm{nSO}_{4}{ }^{2-}+\mathrm{nSO}_{2}\right)\right.$; $\mathrm{n}$ refers to the molar concentration] and nitrate oxidation ratio $\left[\mathrm{NOR}=\mathrm{nNO}_{3}{ }^{-} /\left(\mathrm{nNO}_{3}{ }^{-}+\mathrm{nNO}_{2}\right)\right]$ increased with the $\mathrm{PM}_{2.5}$ level, and heterogeneous processes on the surfaces of fine particles rather than photochemistry drove the haze events. This research elucidates haze formation mechanisms, which must be understood in order to create effective control policies in Tianjin.
\end{abstract}

Keywords: Aerosols; $\mathrm{PM}_{2.5}$; Secondary formation; Tianjin; Winter haze.

\section{INTRODUCTION}

Epidemiological studies have reported that exposure to air pollution, especially fine particulate matter $\left(\mathrm{PM}_{2.5}\right)$, adversely affects human health, including contributing to respiratory and cardiovascular diseases (Peng et al., 2009; Li et al., 2017b). Environmental pollution by $\mathrm{PM}_{2.5}$ has become a serious problem in China, particularly in economically developed regions, such as the Yangtze River Delta region (Shen et al., 2016; Zhang et al., 2016), Pearl River Delta (Tan et al., 2016a; Tan et al., 2016b), and the BeijingTianjin-Hebei region (Ma et al., 2017; Zhang et al., 2018).

The city of Tianjin, located in the southeast area of the

\footnotetext{
* Corresponding author.

Tel.: +86-10-6278-2030

E-mail address: duanfk@tsinghua.edu.cn

** Corresponding author.

Tel.: +86-10-6279-7900

E-mail address: hekb@tsinghua.edu.cn
}

Beijing-Tianjin-Hebei region, faces severe $\mathrm{PM}_{2.5}$ pollution (Tian et al., 2016; Wang et al., 2016; Zhou et al., 2016a). A persistent dense fog event, with a minimum visibility of $117 \mathrm{~m}$, occurred in Tianjin from November 28 to December 2, 2010 (Han et al., 2015). The average $\mathrm{PM}_{2.5}$ concentration in Tianjin was $141.5 \pm 78.0 \mathrm{\mu g} \mathrm{m}^{-3}$ from April 2009 to February 2010 (Zhao et al., 2013) and 148.9 $\pm 91.1 \mu \mathrm{g} \mathrm{m}^{-3}$ over a year long period from 2012-2013 (Zhou et al., 2016a), approximately 2-6 times higher than the National Ambient Air Quality Standards of China (NAAQS; GB$3095-2012$ ) of $35 \mu \mathrm{g} \mathrm{m}^{-3}$. The level of haze pollution over Tianjin increases in winter because of enhanced heating, traffic, and industrial emissions and stable synoptic conditions. However, the current understanding of the sources and formation mechanisms of such pollution haze events is limited. Therefore, assessing the $\mathrm{PM}_{2.5}$ pollution in Tianjin is an urgent requirement.

The purpose of this work was to investigate heavy aerosol pollution during the 2014-2015 winter in Tianjin. In this study, continuous measurements were performed, and the evolutions of $\mathrm{PM}_{2.5}$ and other related gas pollutants, such as $\mathrm{SO}_{2}, \mathrm{O}_{3}$, and $\mathrm{CO}$, were explored under various 
meteorological conditions. Moreover, a back-trajectory model was developed to investigate the transport pathways and potential sources of $\mathrm{PM}_{2.5}$. The aerosol chemical data were then characterized for four high-pollution episodes in January 2015. The relative contributions of meteorological and chemical processes to aerosol concentration during the haze events were discussed, and the formation mechanisms were investigated in detail.

\section{EXPERIMENTAL METHODS}

\section{Sampling Site}

Online ambient observations were performed during the winter of 2014-2015 (December-January-February) on the Nankai University campus $\left(39.13^{\circ} \mathrm{N}, 117.15^{\circ} \mathrm{E}\right)$ in Tianjin. The sampling site is situated approximately $14 \mathrm{~m}$ above the ground level, on the roof of the School of Environment at Nankai University (Fig. 1). There are no major pollution sources near the sampling site.

\section{Instrumentation}

Continuous online observations were carried out for meteorological parameters, the mass concentration of $\mathrm{PM}_{2.5}$, and the mass concentration of the main chemical species in the $\mathrm{PM}_{2.5}$ with values averaged hourly. The mass concentration of $\mathrm{PM}_{2.5}$ was detected using a dichotomous monitor (PM-712; Kimoto Electric, Ltd., Japan) (Duan et al., 2016). The concentration of $\mathrm{H}_{2} \mathrm{O}$, water soluble organic carbon (WSOC), water-soluble inorganic ions $\left(\mathrm{NO}_{3}{ }^{-}\right.$and $\left.\mathrm{SO}_{4}{ }^{2-}\right)$, and optical black carbon $(\mathrm{BC})$ in the $\mathrm{PM}_{2.5}$ were monitored on a dichotomous aerosol chemical speciation analyzer (ACSA-08; Kimoto Electric, Ltd., Japan). The ammonium in the $\mathrm{PM}_{2.5}$ was calculated under the assumption that the ammonium existed as $\mathrm{NH}_{4} \mathrm{NO}_{3}$ and $\left(\mathrm{NH}_{4}\right)_{2} \mathrm{SO}_{4}$ and the particles were neutral (He et al., 2012). The gaseous pollutants $\left(\mathrm{O}_{3}, \mathrm{CO}\right.$, and $\left.\mathrm{SO}_{2}\right)$ were detected by a MCSAM-13 system (Kimoto Electric, Ltd., Japan).
Meteorological parameters, such as relative humidity $(\mathrm{RH})$, temperature, pressure, wind direction (WD), and wind speed (WS), were monitored concurrently.

\section{Trajectory Analysis}

To calculate the backward trajectories of air flows, we used the Hybrid Single Particle Lagrangian Integrated Trajectory (HYSPLIT4) model. The HYSPLIT4 model was developed by the National Oceanic and Atmospheric Administration's (NOAA) Air Resources Laboratory (Stein et al., 2015).

\section{RESULTS AND DISCUSSION}

\section{$P_{2.5}$ Evolution in Winter}

The primary atmospheric pollutant in Tianjin during the winter of 2015 (December-January-February) was $\mathrm{PM}_{2.5}$, with concentrations ranging from 5.6 to $495.6 \mu \mathrm{g} \mathrm{m}^{-3}$ (averaging 112.2 $\pm 96.1 \mathrm{\mu g} \mathrm{m}^{-3}$; Fig. 2). The mass concentrations of $\mathrm{PM}_{2.5}$ and $\mathrm{PM}_{10}$ showed a positive correlation with $\mathrm{R}^{2}$ near 0.87 , the mass concentrations of $\mathrm{PM}_{2.5}$ and $\mathrm{PM}_{10}$ showed a positive correlation with $\mathrm{R}^{2}$ near 0.86 (Fig. S1), and the $\mathrm{PM}_{2.5} / \mathrm{PM}_{10}$ ratio went up as the pollution became more severe (Fig. 2). This suggests that a decrease in $\mathrm{PM}_{2.5}$ levels is critical in reducing particulate matter pollution and improving air quality (Zhou et al., 2016b). A haze episode was observed during the Chinese Spring Festival (January 31-February 7) when large amounts of fireworks were set off, increasing regional $\mathrm{PM}_{2.5}$ pollution levels (Kong et al., 2015). The mean $\mathrm{PM}_{2.5}$ concentrations were 107.2 $\pm 102.6,124.0 \pm 106.1$, and $103.9 \pm 73.4 \mu \mathrm{g} \mathrm{m}^{-3}$ in December, January, and February, respectively (Fig. 3). To better understand the pollution levels, we divided the $\mathrm{PM}_{2.5}$ levels observed during the study period into six categories based on the Air Quality Index of China (Li et al., 2017a): excellent air quality (I; $\mathrm{PM}_{2.5} \leq 35 \mu \mathrm{g} \mathrm{m}^{-3}$ ), good air quality (II; $35<\mathrm{PM}_{2.5} \leq 75 \mu \mathrm{g} \mathrm{m}^{-3}$ ), light pollution



Fig. 1. (a) Google Earth map and (b) the location of the sampling site in Tianjin, China. 


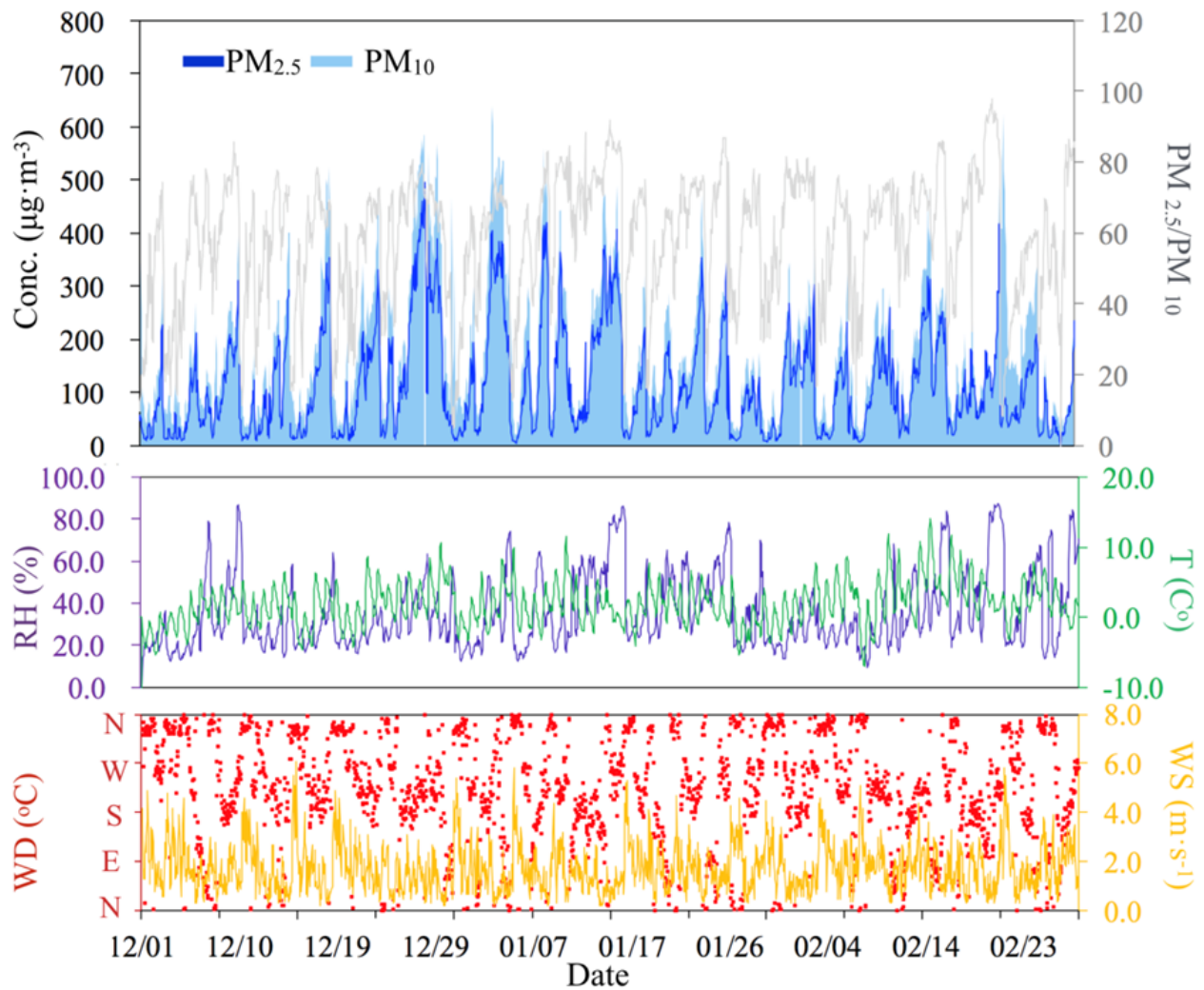

Fig. 2. Time series of $\mathrm{PM}_{10}, \mathrm{PM}_{2.5}, \mathrm{PM}_{10} / \mathrm{PM}_{2.5}$, and meteorological data (temperature (T), relative humidity (RH), wind speed (WS), and wind direction (WD)) in December 2014, January 2015, and February 2015 in Tianjin, China.

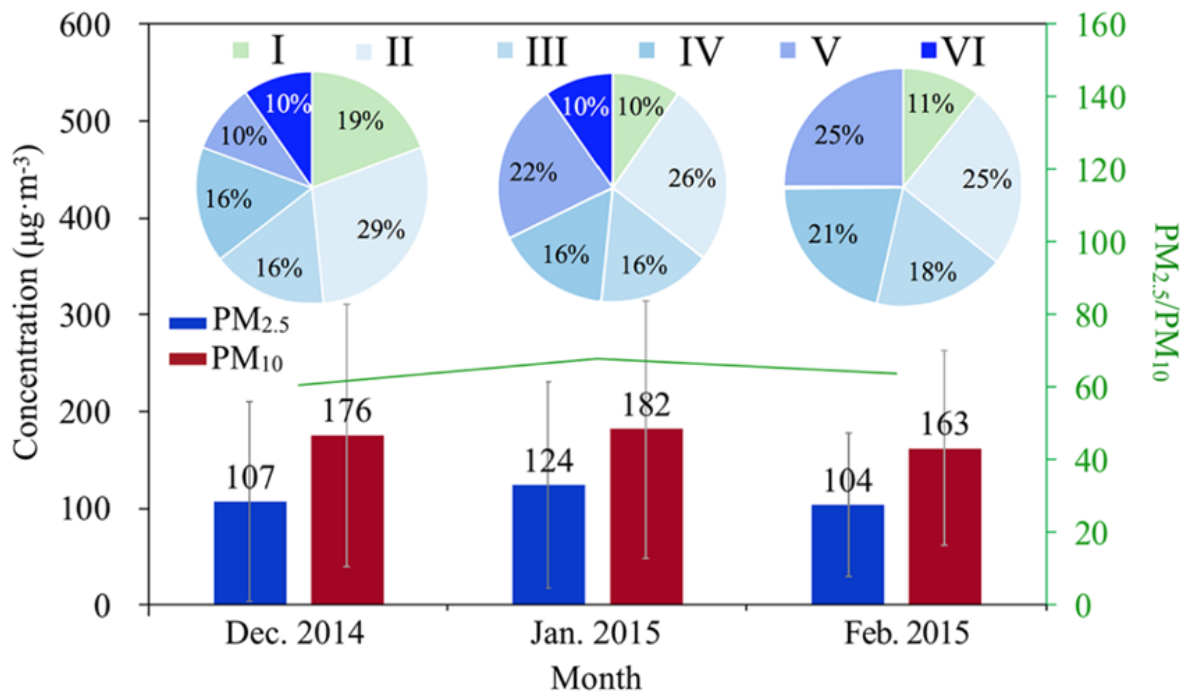

Fig. 3. Monthly average $\mathrm{PM}_{2.5}$ and $\mathrm{PM}_{10}$ concentrations in Tianjin during the winter of 2014-2015. The inset pie charts represent the percentage composition of the $\mathrm{PM}_{2.5}$ levels observed during the study period: excellent air quality $\left(\mathrm{I} ; \mathrm{PM}_{2.5} \leq\right.$ $35 \mu \mathrm{g} \mathrm{m}^{-3}$ ), good air quality (II; $35<\mathrm{PM}_{2.5} \leq 75 \mu \mathrm{g} \mathrm{m}^{-3}$ ), light pollution (III; $75<\mathrm{PM}_{2.5} \leq 115 \mu \mathrm{g} \mathrm{m}^{-3}$ ), moderate pollution (IV; $115<\mathrm{PM}_{2.5} \leq 150 \mu \mathrm{g} \mathrm{m}^{-3}$ ), heavy pollution (V; $150<\mathrm{PM}_{2.5} \leq 250 \mu \mathrm{g} \mathrm{m}^{-3}$ ), and very heavy pollution (VI; $250 \leq$ $\left.\mathrm{PM}_{2.5} \mu \mathrm{g} \mathrm{m}^{-3}\right)$.

(III; $75<\mathrm{PM}_{2.5} \leq 115 \mu \mathrm{g} \mathrm{m}^{-3}$ ), moderate pollution (IV; 115 $<\mathrm{PM}_{2.5} \leq 150 \mu \mathrm{g} \mathrm{m}^{-3}$ ), heavy pollution $\left(\mathrm{V} ; 150<\mathrm{PM}_{2.5} \leq\right.$ $250 \mu \mathrm{g} \mathrm{m}^{-3}$ ), and very heavy pollution (VI; $250 \leq \mathrm{PM}_{2.5}$ $\mu \mathrm{g} \mathrm{m}^{-3}$ ). A similar classification method was adopted by Guo et al. (2016). The inset in Fig. 3 shows the distributions of the monthly $\mathrm{PM}_{2.5}$ levels during the monitoring period; $81 \%, 90 \%$, and $89 \%$ of the days in December, January, and February, respectively, had $\mathrm{PM}_{2.5}$ levels exceeding the NAAQS threshold of $35 \mu \mathrm{g} \mathrm{m}^{-3}$ (Gao, 2013). Therefore, the most severe haze appeared in January during the 2014- 
2015 winter in Tianjin with very heavy pollution on $10 \%$ of the days. The average $\mathrm{PM}_{2.5}$ concentration observed in January in our study was $124 \mu \mathrm{g} \mathrm{m}^{-3}$, similar to the level observed in Tianjin $\left(144.6 \mu \mathrm{g} \mathrm{m}^{-3}\right)$ during a severe haze event in January 2008 (Gu et al., 2011).

Severe $\mathrm{PM}_{2.5}$ pollution characterized by long-lasting and frequent pollution episodes (Fig. 4) was present for most of January. We define an episode as the average daily $\mathrm{PM}_{2.5}$ exceeding $250 \mu \mathrm{g} \mathrm{m}^{-3}$ for a set of consecutive days. Four episodes were observed: January 1-6 (Episode I), January 7-12 (Episode II), January 13-17 (Episode III), and January 18-27 (Episode IV). The maximum episodeaveraged $\mathrm{PM}_{2.5}$ concentration was $168.5 \mu \mathrm{g} \mathrm{m}{ }^{-3}$ during Episode II (Table 1). Additionally, the high average $\mathrm{PM}_{2.5}$ concentrations were long-lasting (5-7 days) and occurred in rapid succession (i.e., intervals between the episodes of $\sim 1$ day). RH showed obvious diurnal cycles, with peaks at night, while temperature displayed the opposite trend, with the highest values appearing during the daytime (Fig. 2). The increased $\mathrm{PM}_{2.5}$ concentration was typically accompanied by increased concentrations of gaseous precursors, lower WS, and higher RH (Fig. 2 and Table S1). These relevancies have been reported in many previous studies ( $\mathrm{Xu}$ et al., 2011; Li et al., 2017a).

\section{Haze Events: Chemical Processes and Formation Mechanisms}

To investigate potential sources and transport pathways of $\mathrm{PM}_{2.5}$ in Tianjin, the NOAA HYSPLIT (ver. 4) model was used to calculate the 24-hour back-trajectories for the days with peak pollution values (January 4, 10, 15, and 23) and the relatively clean days between episodes (January 6 , 12, 17, and 27) of the four pollution episodes in 2015 (Figs. 5(a)-5(d) and S2). For Episode I, II, and IV, particles originated from Hebei Province and Beijing and then moved through the western and southern regions of Tianjin

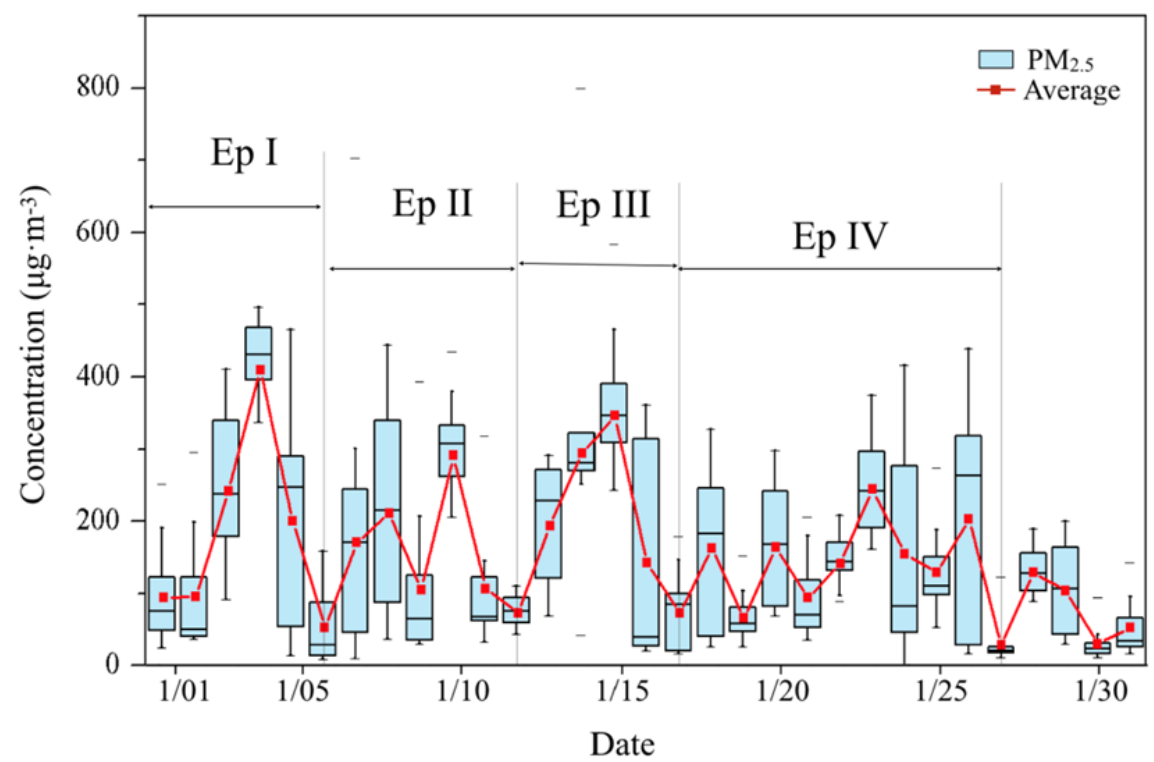

Fig. 4. Statistical results of the daily average $\mathrm{PM}_{2.5}$ concentrations for January 2015. For each box plot, the rectangle spans the $1^{\text {st }}$ quartile to the $3^{\text {rd }}$ quartile, and the central division indicates the median. The whiskers above and below the box show the locations of the $10^{\text {th }}$ and $90^{\text {th }}$ percentiles, respectively. The points above and below the whiskers show the $5^{\text {th }}$ and $95^{\text {th }}$ percentiles, respectively.

Table 1. General information on the severe haze episodes in January 2015.

\begin{tabular}{|c|c|c|c|c|c|c|}
\hline & & Ep. I & Ep. II & Ep. III & Ep. IV & Average \\
\hline \multirow[t]{3}{*}{ Meteorological condition } & $\mathrm{WS}\left(\mathrm{m} \mathrm{s}^{-1}\right)$ & 1.6 & 1.7 & 1.5 & 1.8 & 1.7 \\
\hline & Temp $\left({ }^{\circ} \mathrm{C}\right)$ & 2.0 & 2.2 & 0.8 & 1.1 & 1.4 \\
\hline & RH (\%) & 32.6 & 32.3 & 52.7 & 37.7 & 38.8 \\
\hline \multirow[t]{3}{*}{ PM concentration } & $\mathrm{PM}_{2.5}\left(\mu \mathrm{g} \mathrm{m}^{-3}\right)$ & 168.5 & 134.3 & 158.8 & 89.5 & 124.3 \\
\hline & $\mathrm{PM}_{10}\left(\mu \mathrm{g} \mathrm{m}^{-3}\right)$ & 266.6 & 192.4 & 208.1 & 137.4 & 182.6 \\
\hline & $\mathrm{PM}_{2.5} / \mathrm{PM}_{10}$ & 63.2 & 69.8 & 76.3 & 65.1 & 68.3 \\
\hline \multirow[t]{3}{*}{ Gas pollutants } & $\mathrm{SO}_{2}\left(\mu \mathrm{g} \mathrm{m}^{-3}\right)$ & 33.0 & 26.1 & 19.9 & 20.0 & 23.2 \\
\hline & $\mathrm{O}_{3}\left(\mu \mathrm{g} \mathrm{m}^{-3}\right)$ & 8.1 & 8.7 & 7.3 & 10.3 & 9.1 \\
\hline & $\mathrm{NO}_{2}\left(\mu \mathrm{g} \mathrm{m}^{-3}\right)$ & 52.8 & 57.8 & 49.9 & 52.8 & 52.6 \\
\hline \multirow[t]{3}{*}{ SNA concentration in $\mathrm{PM}_{2.5}$} & $\mathrm{SO}_{4}{ }^{2-}\left(\mu \mathrm{g} \mathrm{m}^{-3}\right)$ & 14.6 & 9.5 & 39.9 & 23.9 & 19.6 \\
\hline & $\mathrm{NO}_{3}^{-}\left(\mu \mathrm{g} \mathrm{m}^{-3}\right)$ & 21.8 & 18.8 & 25.4 & 16.2 & 17.7 \\
\hline & $\mathrm{NH}_{4}^{+}\left(\mu \mathrm{g} \mathrm{m}^{-3}\right)$ & 10.2 & 7.3 & 20.4 & 12.2 & 11.2 \\
\hline
\end{tabular}


to the study area. For Episode III, particles predominantly originated from the southwestern region of Tianjin, passing over the eastern region and circling around the study area. The high levels of $\mathrm{PM}_{2.5}$ observed on January 15 (averaging $361 \mu \mathrm{g} \mathrm{m}^{-3}$ ) could be due to whirling winds, a high RH of $52.7 \%$, and a low WS of $1.5 \mathrm{~m} \mathrm{~s}^{-1}$. The RH in this event was about $20 \%$ higher than in others (Table 1) as the movement of the air mass near Bohai Bay may have facilitated the secondary conversion of aerosols. Finally, the trajectory shifted sharply to the north (for Episode I, III, and IV) or south (for Episode II) with high wind speed and the haze abruptly disappearing. Approximately 23$58 \%$ of the $\mathrm{PM}_{2.5}$ mass concentrations were measured by six components (Figs. 5(e)-5(1)). Three major secondary ionic species (sulfate, nitrate, and ammonium (SNA)) contributed $3-21 \%, 8-14 \%$, and $4-11 \%$ of the total $\mathrm{PM}_{2.5}$, respectively, while $\mathrm{H}_{2} \mathrm{O}$ contributed 2-10\%. BC and WSOC accounted for about $1-3 \%$ and $2-3 \%$ of $\mathrm{PM}_{2.5}$, respectively. Correlations between chemical components of $\mathrm{PM}_{2.5}$ were determined through regression analysis
(Table S3). The unidentified portion of the $\mathrm{PM}_{2.5}$ mass might be organic matter $(\mathrm{OM})$, crustal matter, and trace metal elements. As reported previously ( $\mathrm{Gu}$ et al., 2011), $\mathrm{OM}$ was a predominant fraction of $\mathrm{PM}_{2.5}$, accounting for $\sim 32.7 \%$. However, it was not measured in this study and deserves greater attention in future studies. In addition to OM, SNA was an important cause of the reduction in visibility and regional haze pollution and was the dominant component of $\mathrm{PM}_{2.5}$ (Guo et al., 2014). Here we focus more on the measured SNA. The chemical composition varied with increasing severity of pollution, and the proportion of SNA was found to be increasing, especially in Episode III (Figs. 5(g) and 5(k)). Nitrate increased from $14 \%$ to $21 \%$, from clean to heavily polluted; sulfate increased from $9 \%$ to $12 \%$; and ammonium rose from $7 \%$ to $11 \%$. The backtrajectories and chemical composition results indicated that the secondary ionic species of aerosols were one of the important causes of the haze episode. The regional transport of $\mathrm{PM}_{2.5}$ also played a big role in haze formation.

To assess the contributions of chemical processes to
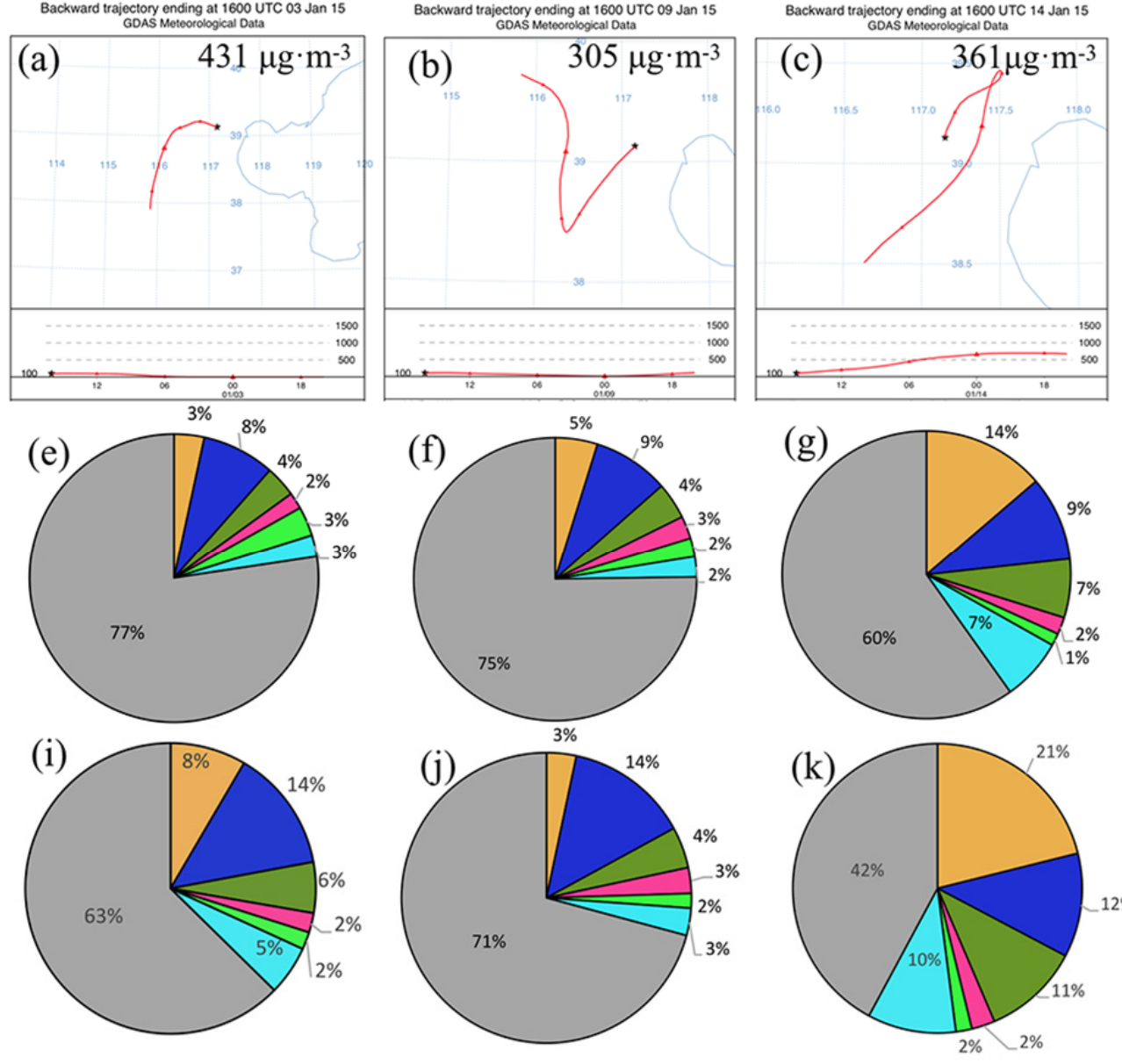

$\square \mathrm{SO}_{4}{ }^{2-}$

$\square \mathrm{NO}_{3}^{-}$

$\square \mathrm{NH}_{4}^{+}$

- WSOC

$\square \mathrm{BC} \quad \square \mathrm{H}_{2} \mathrm{O}$

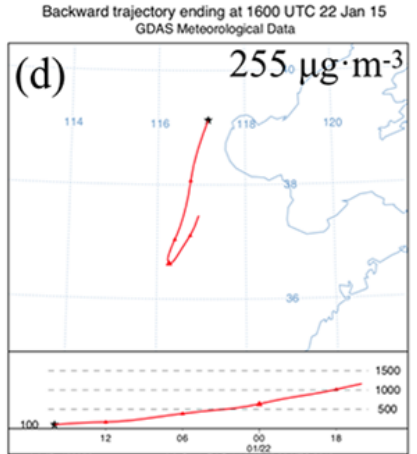

(h)

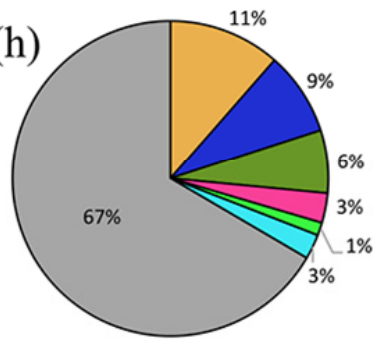

(1)

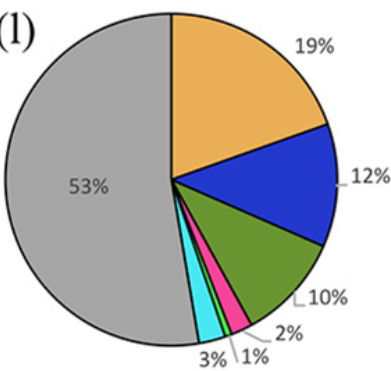

$\square$ Other

Fig. 5. 24-hour back-trajectories for air masses arriving at Tianjin on the days with the peak pollution values during the pollution episodes: (a) January 4, (b) January 10, (c) January 15, and (d) January 23 in 2015. Chemical composition of $\mathrm{PM}_{2.5}$ on clean days $\left(\mathrm{PM}_{2.5} \leq 75 \mu \mathrm{g} \mathrm{m}^{-3}\right)$ : (e) January 1, (f) January 6, (g) January 12, and (h) January 17; and on peak pollution days: (i) January 4, (j) January 10, (k) January 15, and (l) January 23 during the four pollution episodes in 2015 in Tianjin. Calculations begin at $100 \mathrm{~m}$ above ground and continue for $24 \mathrm{~h}$. 

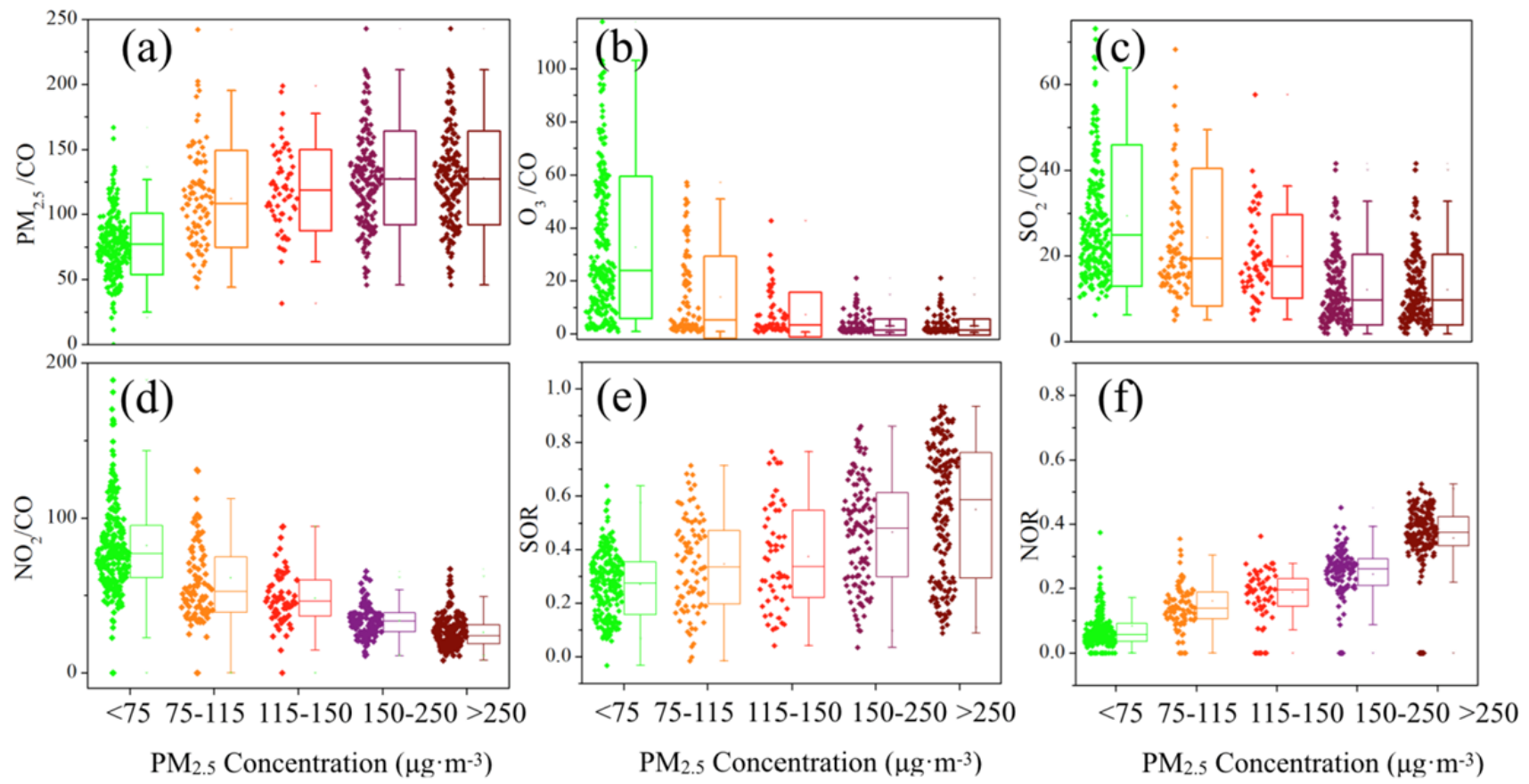

Fig. 6. Measured ratios of (a) $\mathrm{PM}_{2.5} / \mathrm{CO}$, (b) $\mathrm{SO}_{2} / \mathrm{CO}$, (c) $\mathrm{O}_{3} / \mathrm{CO}$, and (d) $\mathrm{NO}_{2} / \mathrm{CO}$ for different $\mathrm{PM}_{2.5}$ levels. Variation in the (e) sulfur oxidation ratio (SOR) and (f) nitrate oxidation ratio (NOR) with pollution levels.

aerosol concentrations during haze events, $\mathrm{CO}$ was selected as a chemically inactive tracer. The chemical lifetime of $\mathrm{CO}$, which is on the order of a few months, depends on $\mathrm{OH}$ concentrations (Brasseur, 1999; Zhang et al., 2015). The ratios of $\mathrm{PM}_{2.5} / \mathrm{CO}, \mathrm{O}_{3} / \mathrm{CO}, \mathrm{NO}_{2} / \mathrm{CO}$, and $\mathrm{SO}_{2} / \mathrm{CO}$ were analyzed at different $\mathrm{PM}_{2.5}$ levels (Fig. 6). The results showed that the $\mathrm{PM}_{2.5} / \mathrm{CO}$ ratio (Fig. 6(a)) increased with increasing $\mathrm{PM}_{2.5}$ levels, suggesting that secondary $\mathrm{PM}_{2.5}$ aerosol levels increased during the haze episodes. The $\mathrm{O}_{3} / \mathrm{CO}$ ratio (Fig. 6(b)) rapidly decreased when the $\mathrm{PM}_{2.5}$ concentrations increased from 75 to $250 \mu \mathrm{g} \mathrm{m}^{-3}$ and remained at very low levels when the $\mathrm{PM}_{2.5}$ concentration rose above $250 \mu \mathrm{g} \mathrm{m}^{-3}$, indicating that the photochemical production of $\mathrm{O}_{3}$ ceased during the high $\mathrm{PM}_{2.5}$ periods, similar to results reported in other studies (Bian et al., 2007). SOR and NOR are often used as indicators of secondary transformation of $\mathrm{SO}_{2}$ and $\mathrm{NO}_{2}$ to form $\mathrm{SO}_{4}{ }^{2-}$ and $\mathrm{NO}_{3}{ }^{-}$, respectively (Zheng et al., 2015; Xu et al., 2017). Higher SOR and NOR (Figs. 6(e)-6(f)) values were observed during the polluted periods than during clean periods, while the $\mathrm{SO}_{2} / \mathrm{CO}$ and $\mathrm{NO}_{2} / \mathrm{CO}$ rapidly decreased with increasing $\mathrm{PM}_{2.5}$ levels (Figs. 6(c)-6(d)). The results further indicated that the secondary aerosol levels were elevated on haze days, and it was hypothesized that the transformation of enhanced secondary aerosols was most likely driven by heterogeneous processes because the photochemical production of ozone ceased concurrently.

$\mathrm{RH}$ is generally regarded as one of the main factors facilitating the formation of haze through heterogeneous reactions (Chen et al., 2016). The heterogeneous reactions in the following discussion cover both aqueous-phase reactions and gas-particle partitioning. As shown in Fig. S3, as the RH increased from $12 \%$ to $86 \%$, the SOR value exhibited an increasing trend, with high correlation $\left(\mathrm{R}^{2}=\right.$ 0.64). The size and surface area of the particles was enlarged with the increased RH. Thus, the pre-existing $\mathrm{SO}_{4}{ }^{2-}$ were able to absorb water, which facilitated their capacity to accommodate aqueous-phase reactions (Cheng et al., 2015, Li et al., 2017a). Meanwhile, the particle viscosity decreased due to high $\mathrm{RH}$. The mass transfer limits for gaseous pollutants into particle phase were kinetically elevated. Consequently, more pollutants were transferred into the particle phase, which aided the heterogeneous reactions (George et al., 2015). Therefore, enhanced secondary transformation during the haze events was mainly driven by heterogeneous processes, not the photochemistry.

\section{CONCLUSIONS}

During the winter of 2014-2015 in Tianjin, China, the most severe $\mathrm{PM}_{2.5}$ pollution, comprising four haze episodes, was observed in January. The secondary formation of aerosols was a primary cause of these episodes, and regional transport of $\mathrm{PM}_{2.5}$ also played a main role. When $\mathrm{PM}_{2.5}$ levels were high, the formation of secondary $\mathrm{PM}_{2.5}$ increased, and the photochemical production of $\mathrm{O}_{3}$ ceased. This study's analysis of $\mathrm{PM}_{2.5}$ 's chemical signatures contributes to our understanding of the current air pollution in Tianjin and can be used to improve model validation and emission control.

\section{ACKNOWLEDGEMENTS}

We acknowledge the HYSPLIT transport and dispersion model provided by the NOAA Air Resources Laboratory. We acknowledge the financial support of the National 
Science and Technology Program of China (grant nos. 2017YFC0211502, 2014BAC22B01, 2016YFC0202700, and 2017YFC0211601), the National Natural Science Foundation of China (grant nos. 21707077 and 81571130090), the Science Fund for Creative Research Groups (grant no. 21521064), and the China Postdoctoral Science Foundation (grant no. 2017M610923).

\section{SUPPLEMENTARY MATERIAL}

Supplementary data associated with this article can be found in the online version at http://www.aaqr.org.

\section{REFERENCES}

Bian, H., Han, S., Tie, X., Sun, M. and Liu, A. (2007). Evidence of impact of aerosols on surface ozone concentration in Tianjin, China. Atmos. Environ. 41: 4672-4681.

Brasseur, G.P., Orlando, J.J. and Geoffrey, S. (1999). Atmospheric chemistry and global change. Oxford University Press.

Chen, D., Liu, Z.Q., Fast, J. and Ban, J.M. (2016). Simulations of sulfate-nitrate-ammonium (SNA) aerosols during the extreme haze events over northern China in October 2014. Atmos. Chem. Phys. 16: 10707-10724.

Cheng, Y., He, K.B., Du, Z.Y., Zheng, M., Duan, F.K. and Ma, Y.L. (2015). Humidity plays an important role in the $\mathrm{PM}_{2.5}$ pollution in Beijing. Environ. Pollut. 197: 6875.

Duan, F.K., He, K.B., Ma, Y.L., Ihozaki, T., Kawasaki, H., Arakawa, R., Kitayama, S., Tujimoto, K., Huang, T. and Kimoto, T. (2016). High molecular weight organic compounds (HMW-OCs) in severe winter haze: Direct observation and insights on the formation mechanism. Environ Pollut. 218: 289-296.

Gao, F. (2013). Evaluation of the Chinese New Air Quality Index (Gb3095-2012): Based on Comparison with the US AQI System and the WHO AQGs. Degree Thesis, Integrated Coastal Zone Management, Raseborg, Finland.

George, C., Ammann, M., D'Anna, B., Donaldson, D.J. and Nizkorodov, S.A. (2015). Heterogeneous photochemistry in the atmosphere. Chem. Rev. 115: 4218-4258.

Gu, J.X., Bai, Z.P., Li, W.F., Wu, L.P., Liu, A.X., Dong, H.Y. and Xie, Y.Y. (2011). Chemical composition of $\mathrm{PM}_{2.5}$ during winter in Tianjin, China. Particuology 9: 215-221.

Guo, H., Cheng, T., Gu, X., Chen, H., Wang, Y., Zheng, F. and Xiang, K. (2016). Comparison of four ground-level $\mathrm{PM}_{2.5}$ estimation models using PARASOL aerosol optical depth data from China. Int. J. Environ. Res. Public Health 13: 180.

Guo, S., Hu, M., Zamora, M.L., Peng, J., Shang, D., Zheng, J., Du, Z., Wu, Z., Shao, M., Zeng, L., Molina, M.J. and Zhang, R. (2014). Elucidating severe urban haze formation in China. Proc. Natl. Acad. Sci. U.S.A. 111: 17373-17378.

Han, S.Q., Cai, Z.Y., Zhang, Y.F., Wang, P., Yao, Q., Li, P.Y. and Li, X.J. (2015). Long-term trends in fog and boundary layer characteristics in Tianjin, China. Particuology 20: 61-68.

He, K., Zhao, Q., Ma, Y., Duan, F., Yang, F., Shi, Z. and Chen, G. (2012). Spatial and seasonal variability of $\mathrm{PM}_{2.5}$ acidity at two Chinese megacities: insights into the formation of secondary inorganic aerosols. Atmos. Chem. Phys. 11: 25557-25603.

Kong, S.F., Li, X.X., Li, L., Yin, Y., Chen, K., Yuan, L., Zhang, Y.J., Shan, Y.P. and Ji, Y.Q. (2015). Variation of polycyclic aromatic hydrocarbons in atmospheric $\mathrm{PM}_{2.5}$ during winter haze period around 2014 Chinese Spring Festival at Nanjing: Insights of source changes, air mass direction and firework particle injection. Sci. Total Environ. 520: 59-72.

Li, H., Ma, Y., Duan, F., He, K., Zhu, L., Huang, T., Kimoto, T., Ma, X., Ma, T. and Xu, L. (2017a). Typical winter haze pollution in Zibo, an industrial city in China: Characteristics, secondary formation, and regional contribution. Environ Pollut. 229: 339-349.

Li, H.M., Wu, H.F., Wang, Q.G., Yang, M., Li, F.Y., Sun, Y.X., Qian, X., Wang, J.H. and Wang, C. (2017b). Chemical partitioning of fine particle-bound metals on haze-fog and non-haze-fog days in Nanjing, China and its contribution to human health risks. Atmos. Res. 183: 142-150.

Ma, Q., Wu, Y., Tao, J., Xia, Y., Liu, X., Zhang, D., Han, Z., Zhang, X. and Zhang, R. (2017). Variations of chemical composition and source apportionment of $\mathrm{PM}_{2.5}$ during winter haze episodes in Beijing. Aerosol Air Qual. Res. 17: 2791-2803.

Peng, R.D., Bell, M.L., Geyh, A.S., Mcdermott, A., Zeger, S.L., Samet, J.M. and Dominici, F. (2009). Emergency admissions for cardiovascular and respiratory diseases and the chemical composition of fine particle air pollution. Environ. Health Perspect. 117: 957-963.

Shen, L.J., Wang, H.L., Lu, S., Li, L., Yuan, J., Zhang, X.H., Tian, X.D. and Tang, Q. (2016). Observation of aerosol size distribution and new particle formation at a coastal city in the Yangtze River Delta, China. Sci. Total Environ. 565: 1175-1184.

Stein, A.F., Draxler, R.R., Rolph, G.D., Stunder, B.J.B., Cohen, M.D. and Ngan, F. (2015). NOAA's HYSPLIT atmospheric transport and dispersion modeling system. Bull. Am. Meteorol. Soc. 96: 2059-2077.

Tan, H.B., Liu, L., Fan, S.J., Li, F., Yin, Y., Cai, M.F. and Chan, P.W. (2016a). Aerosol optical properties and mixing state of black carbon in the Pearl River Delta, China. Atmos. Environ. 131: 196-208.

Tan, J.H., Duan, J.C., Ma, Y.L., He, K.B., Cheng, Y., Deng, S.X., Huang, Y.L. and Si-Tu, S.P. (2016b). Longterm trends of chemical characteristics and sources of fine particle in Foshan City, Pearl River Delta: 20082014. Sci. Total Environ. 565: 519-528.

Tian, Y.Z., Chen, G., Wang, H.T., Huang-Fu, Y.Q., Shi, G.L., Han, B. and Feng, Y.C. (2016). Source regional contributions to $\mathrm{PM}_{2.5}$ in a megacity in China using an advanced source regional apportionment method. Chemosphere 147: 256-263.

Wang, J., Zhou, M., Liu, B.S., Wu, J.H., Peng, X., Zhang, 
Y.F., Han, S.Q., Feng, Y.C. and Zhu, T. (2016). Characterization and source apportionment of sizesegregated atmospheric particulate matter collected at ground level and from the urban canopy in Tianjin. Environ. Pollut. 219: 982-992.

Xu, L.L., Duan, F.K., He, K.B., Ma, Y.L., Zhu, L.D., Zheng, Y.X., Huang, T., Kimoto, T., Ma, T., Li, H., Ye, S.Q., Yang, S., Sun, Z.L. and Xu, B.Y. (2017). Characteristics of the secondary water-soluble ions in a typical autumn haze in Beijing. Environ. Pollut. 227: 296-305.

Xu, W.Y., Zhao, C.S., Ran, L. and Deng, Z.Z. (2011). Characteristics of pollutants and their correlation to meteorological conditions at a suburban site in the North China Plain. Atmos. Chem. Phys. 11: 4353-4369.

Zhang, B., Wang, Y. and Hao, J. (2015). Simulating aerosol-radiation-cloud feedbacks on meteorology and air quality over eastern China under severe haze conditionsin winter. Atmos. Chem. Phys. 15: 23872404.

Zhang, H.F., Wang, S.X., Hao, J.M., Wang, X.M., Wang, S.L., Chai, F.H. and Li, M. (2016). Air pollution and control action in Beijing. J. Clean Prod. 112: 15191527.

Zhang, Z., Ma, Z. and Kim, S.J. (2018). Significant decrease of $\mathrm{PM}_{2.5}$ in Beijing based on long-term records and Kolmogorov-Zurbenko filter approach. Aerosol Air Qual. Res. 18: 711-718.

Zhao, P.S., Dong, F., Yang, Y.D., He, D., Zhao, X.J., Zhang, W.Z., Yao, Q. and Liu, H.Y. (2013). Characteristics of carbonaceous aerosol in the region of Beijing, Tianjin, and Hebei, China. Atmos. Environ. 71: 389-398.

Zheng, G.J., Duan, F.K., Su, H., Ma, Y.L., Cheng, Y., Zheng, B., Zhang, Q., Huang, T., Kimoto, T. and Chang, D. (2015). Exploring the severe winter haze in Beijing: the impact of synoptic weather, regional transport and heterogeneous reactions. Atmos. Chem. Phys. 15: 29692983.

Zhou, J.B., Xing, Z.Y., Deng, J.J. and Du, K. (2016a). Characterizing and sourcing ambient $\mathrm{PM}_{2.5}$ over key emission regions in China I: Water-soluble ions and carbonaceous fractions. Atmos. Environ. 135: 20-30.

Zhou, X.H., Cao, Z.Y., Ma, Y.J., Wang, L.P., Wu, R.D. and Wang, W.X. (2016b). Concentrations, correlations and chemical species of $\mathrm{PM}_{2.5} / \mathrm{PM}_{10}$ based on published data in China: Potential implications for the revised particulate standard. Chemosphere 144: 518-526.

Received for review, April 25, 2018 Revised, April 28, 2019 Accepted, May 5, 2019 